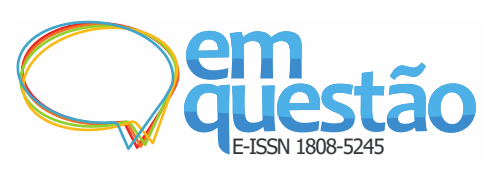

\title{
Publishing during a pandemic: comparison of scientific knowledge between COVID-19 and Swine
}

\section{Flu}

\author{
Bianca Pinto Vieira \\ Doctor; Universidade Federal de Santa Catarina, Florianópolis, SC, Brazil; \\ biancabioufsc@gmail.com; ORCID: http://orcid.org/0000-0002-6847-6908
}

\begin{abstract}
Scientific knowledge has a well-established cycle of generating hypotheses, testing them in experiments with proper discussion, and submitting it to the scientific community analysis through publications. It takes time to establish sample size for biomedical studies, especially concerning the effect of medicines and vaccines. The World Health Organization's protocol estimates that more than 19 months of experiments are necessary to approve a vaccine, for example. As the world has witnessed, a pandemic with immediate impact on human lives urges scientific methods to speed up finding solutions. Here it was assessed the speed and volume of information generated by the Academia to tackle the COVID-19 compared to the Swine Flu pandemic. Were considered papers published in journals indexed in PubMed, the most comprehensive biomedical scientific database available online. The number of publications about COVID-19 was 11 times higher than the number of publications about Swine Flu in a one-year timeframe. Though the expectation were finding more international collaborations and studies focusing on vaccines for COVID-19, papers were mostly concentrated in China and studying symptoms, managing the pandemic, reviewing knowledge, or establishing clinical trials. For sure, science is working faster every day for solutions in biomedical critical situations. However, the fast volume of information might blurry decisions on public health management. This paper's results show it is mandatory before using papers to take actions, waiting for the scientific community to first progress on its scientific knowledge cycle and mature discussions on the generated knowledge.
\end{abstract}

Keywords: Coronavirus; Viral diseases; Pubmed database; Value of information; Scientific knowledge cycle

\section{Introduction}

The scientific knowledge starts with a need or the curiosity for a subject that leads to a hypothesis which is tested with proper sampling design, generating 
results that are published and submitted to other scientists' testing and discussions (HACKING, 1983; DANE, 1990). Depending on the subject, a conclusion comes after months or years yet there is a clear difference between the speed of publications in the 19th and in the 21st Century. While philosophers and naturalists used to publish papers and books that would take months to get on universities and libraries, and communications through mostly letters would take time to cross continents by the 19th and the 20th Century, nowadays scientists have access to pre-prints before publishing and answers are as fast as an email can deliver. The current technology opens the opportunity to check a greater amount of data and information faster than ever. Therefore, it would be expected science to also develop faster and solve humanity's urgent needs. However, scientific knowledge needs a minimal amount of time to mature through publications and discussions before being useful to society and, in some situations, it can be frustrating to the public opinion waiting for it.

A particular case when Science becomes urgent is during a pandemic. Pandemics are "[...] epidemics on the basis of worldwide spread and cause excessive number of sickness, deaths in the world and cause disruption for social economic situation of the countries which were affected." (AKIN; GÖZEL, 2020, p. 515). The lack of knowledge about the impacts of a bacteria, virus or other biological entity over humanity and its main resources, especially if the transmission rate is high, creates a disastrous situation on society's management (AKIN; GÖZEL, 2020). It takes time to establish a proper sample size for biomedical studies especially concerning the effect of new treatments and vaccines. The World Health Organization's protocol estimates more than 19 months of experiments are necessary to approve a vaccine, for example (WHO, 2010a).

The plague of Justinian struck in the 6th Century and killed as many as 50 million people, perhaps half the global population at the time. The Black Death of the 14th Century - likely caused by the same pathogen - may have killed up to 200 million people. Smallpox may have killed as many as 300 million people in the 20th Century alone, even though an effective vaccine - the world's first - had been available since 1796. When traditional decisions cannot 
hold a situation, only the extent of testing hypotheses and development of disruptive solutions come as a way out of crisis.

It is logical that when increasing the speed and amount of available data, taking decisions becomes a more complex process. According to Baum and Wally (2003), speed of strategic decisions depends on organization's design and environmental selection. However, when the environment is under pressure, Smith and Hayne (1997) point out quality of decisions suffers and the chances of following the right paths are related to manager's ability to deal with work process, communication, depth of analysis, task focus, and influence over the processes. At the spectrum depth of analysis in a pandemic, it depends on managers ability to debug scientific knowledge and understand when it is mature enough for wide use.

Therefore, analysing the publishing patterns during a pandemic helps understanding how information is produced and hopefully increases authorities' possibilities of making better choices for human needs. I therefore compared scientific knowledge between the current pandemic caused by the COVID-19 and the last decade pandemic caused by the Swine Flu. I used a web scraping method to classify papers and books indexed in the database PubMed $\AA$. I considered both diseases because these pandemics occurred during the 21th Century when internet and online publishing were already well established. I assessed the papers generated by the Academia to tackle the COVID-19 compared to the Swine Flu pandemics expecting the speed and volume of publications might be higher when the subject is the COVID-19. Also, I expected the number of publications per country to be higher about the COVID19 than about the Swine Flu due to wider global access to information and possible international collaborations. And, considering the global situation that the Swine Flu affected less of societies' structure (e.g. transportation, economy, and social life) than the COVID-19, I expected more papers looking for vaccines and treatments when studying the COVID-19 than the Swine Flu. Thus, this study explores the value of information from the scientific community based on patterns of global publications. 


\section{Methods}

The Coronavirus Sars-CoV-2 causes the COVID-19, an infectious disease identified in 2020 (WHO, 2020). The spread of COVID-19 started in November 2019 in China and got the attention of other countries such as Taiwan in December 2019. The COVID-19 pandemic was recognised by the World Health Organization (WHO) by 11 March 2020 (SINGH et al., 2020) and by the date of this publication it was still ongoing, with more than 4.5 million deaths and first doses of vaccines developed and tested throughout the year already in use.

The Swine Flu pandemic was caused by the Influenza virus and recorded between 2009 and 2010 (TRIFONOV et al., 2009). There were around 18,500 lab-recorded deaths in the world, but statistical modelling suggests the number of deaths are likely 570,000 (SAUNDERS-HASTINGS; KREWSKI, 2016).

To analyse the production of scientific knowledge during both pandemics, I reviewed a total of 139,482 results by web scraping an online database. Records covered a period from April 1919 to December 2020. I considered the database PubMed $\AA$, which is a free source research database comprising 30 million citations about biomedical and life sciences literature (PUBMED, 2020). The database is available in www.pubmed.ncbi.nlm.nih.gov and maintained by the National Center for Biotechnology Information, at the U.S. National Library of Medicine, located at the National Institutes of Health (PUBMED, 2020). I performed searches for each disease independently and terms were not case sensitive (Table 1).

Table 1 - List of terms for each disease searched on web databases.

Disease

Terms

\begin{tabular}{ll}
\hline COVID-19 "COVID-19" or "Wuhan flu" or "Sars-cov-2" or "new coronavirus" or "coronavirus flu" \\
Swine Flu & $\begin{array}{l}\text { "Swine Flu" or "swine influenza" or "SIV" or "S-OIV" or "swine-origin influenza virus" } \\
\text { or "influenza C H1N1" or "influenza A subtypes H1N2, H2N3, H3N1 and H3N2" }\end{array}$ \\
\hline
\end{tabular}

Souce: Research data.

The data in HTML and XML were structured and required using the xml2 1.2.2 (WICKHAM, 2020) and the httr 1.4.1 packages (WICKHAM, 2019a) in R 4.0.2 (R CORE DEVELOPMENT TEAM, 2020). I used the rvest 0.3.5 package (WICKHAM, 2019b) to web scraping and data extraction by 
keywords from the title, date of publication, and journal. Data were cleaned for repetition, reports, and editorials. From all papers, I considered only a year timeframe for each pandemic in order to account for variation through time. Therefore, papers on Swine Flu were considered only from December 2009 to December 2010, and papers on COVID-19 were considered from December 2019 to December 2020.

These timeframes were chosen to cover for the peak of each pandemic. After data treatment, I had a total of 50,302 papers. I fitted a linear regression to papers published by month to estimate publishing trends during the pandemics. For each pandemic, I estimated the Co-authorship Index (CI) representing the collaboration between researchers in findings. The CI is found by dividing the total number of authors by the total number of papers. The analysis considered the author's names as "NameInitials" with no space (e.g. SmithW) so I could account for writing variabilities maintaining individuality. For the 150 mostproductive authors (despite being first authors or not) in each studied pandemic, I extracted their institutions and countries. I selected the 150 most-productive authors because they were responsible for 46\% (Swine Flu) and 42.4\% (COVID-19) of the published papers, more than the sample needed (Swine Flu $=38 \%$, COVID-19 $=34 \%$, standard error $=0.01$, confidence $=99 \%$ ) to represent patterns for the total of papers. I tested the data distribution and used the Mann-Whitney Test to check for differences in the global distribution of the 150 most-productive authors publishing about Swine Flu and COVID-19.

As a good scientific title should address the paper's subject, I considered the title as a proxy of the main theme. To highlight the most frequently used keywords in papers' titles, I performed a text mining using the tm package (FEINERER; HORNIK, 2019) associated with a word-cloud generator in the wordcloud package (FELLOWS, 2018) in R 4.0.2 (R CORE DEVELOPMENT TEAM, 2020). I excluded grammatical artifacts and the main terms from Table 1 thus analysing 26,208 words from titles of papers on Swine Flu and 404,753 words from titles of papers on COVID-19. The word cloud analysis considered only words with frequency higher than 50 uses for Swine Flu and 500 for COVID-19. I also checked the frequency of words for the ten most-used terms. 


\section{Results}

I analysed 4,231 papers on Swine Flu from December 2009 to December 2010. Authorship ranged from 1 to 85 authors/paper, totalling 18,048 authors. The CI was 4.26. The paper with most authors (L'VOV et al., 2010) presented the sequence analysis of 150 positive samples collected six months before publication.

The analysis on COVID-19 resulted in 46,839 papers from December 2019 to December 2020. Authorship ranged from 1 to 205 authors/paper, totalling 156,005 authors. The CI was 3.33. The paper with most authors (DI MASCIO et al., 2020) focused on the risk factors associated with adverse fetal outcomes in pregnancies affected by COVID-19.

There was a clear difference between patterns of publication between the Swine Flu and the COVID-19 pandemics (Figure 1). The Swine Flu pandemic had a declining pattern in the number of published papers $(\beta=-10.69$, degrees of freedom $=11, R^{2}=0.49, p$-value $\left.=0.004\right)$ with its peak within the selected timeframe in December $2009(\mathrm{n}=413$, Figure 1A). The monthly average of publications was $266.46(95 \%$-confidence interval $= \pm 31.64)$. On the other hand, the COVID-19 pandemic presented a positive pattern of publications $(\beta=$ 1005.9 , degrees of freedom $=11, R^{2}=0.82, p$-value $\left.<0.001\right)$ with its peak in September $2020(\mathrm{n}=11,405$, Figure 1B). The monthly average of publications was 5,282.46 (95\%-confidence interval $= \pm 2,371.37)$. 
Figure 1 - Distribution of publications about Swine Flu (A.) from December 2009 to December 2010 and about COVID-19 (B.) from December 2019 to December 2020 in journals indexed in the PubMed database.

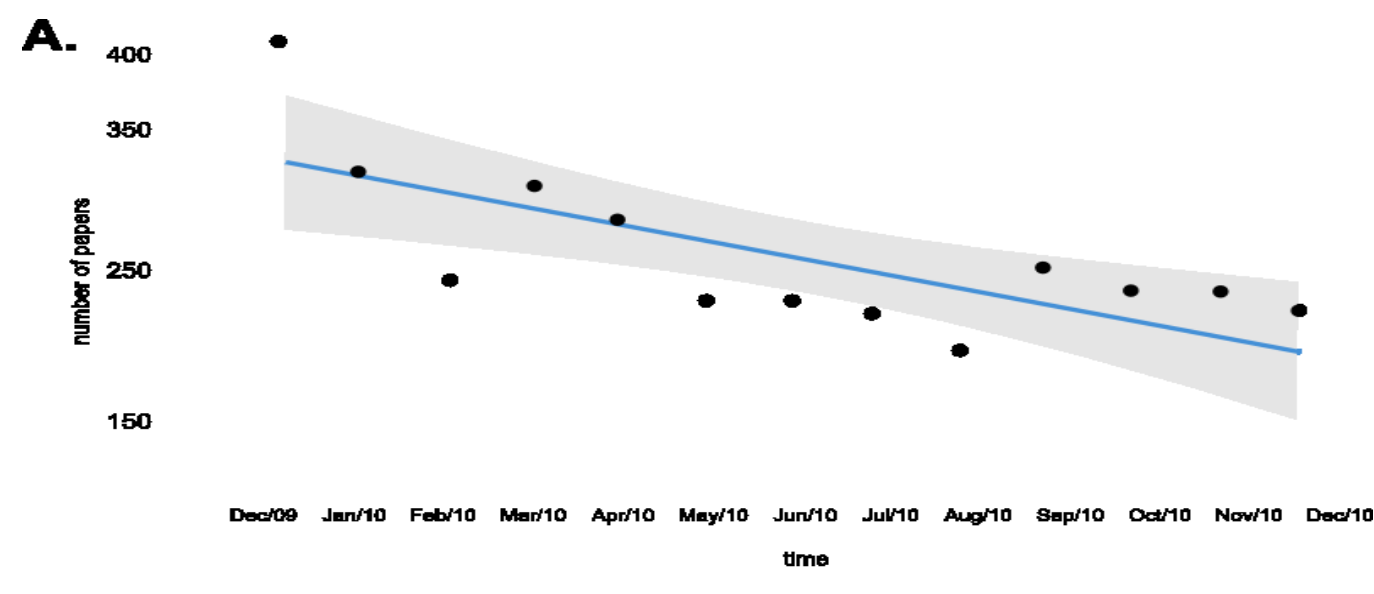

B.

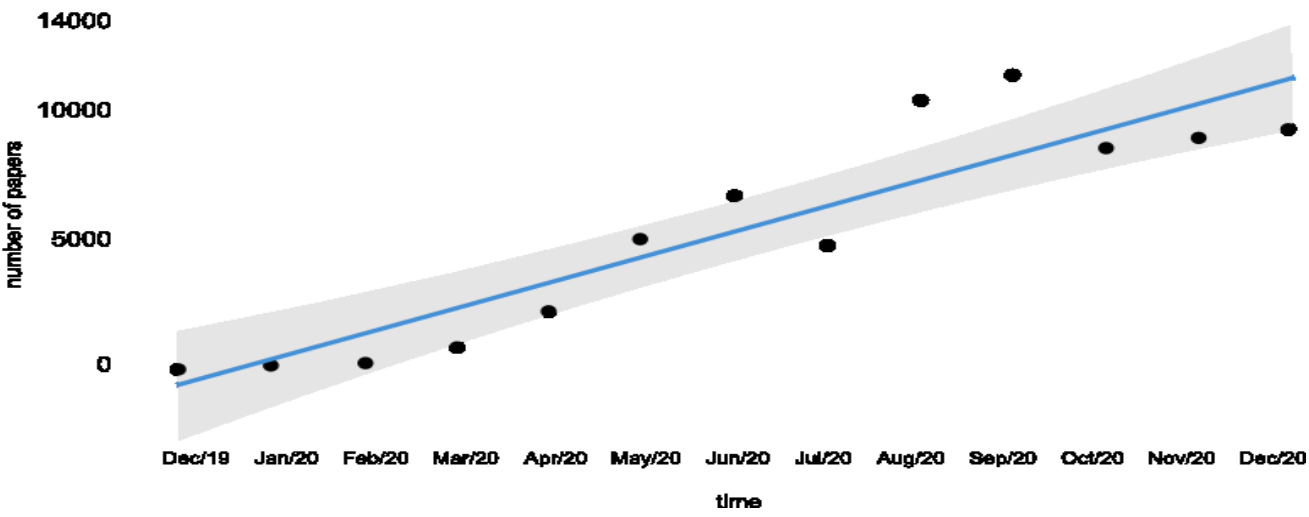

Source: Research data.

The Mann-Whitney Test pointed out that the global distribution of the 150 most-productive authors publishing about Swine Flu and COVID-19 was significantly different $(\mathrm{V}=55, p$-value $=0.006)$. The 150 most-productive authors writing about Swine Flu were based on 17 countries and 66 institutions (Table 2, Figure 2). These authors were responsible for $46 \%$ of all scientific publishing on this subject and produced 13.03 papers on average. Only three institutions published more than 100 papers during the studied period (Table 3): the University of Hong Kong (Hong Kong), the Harbin Medical University (China), and the Center for Disease Control and Prevention (USA).

Despite the expectations of wider international collaboration through a spread of authors and publications across the globe, the 150 most-productive authors writing about COVID-19 were mainly based on China, though other nine countries are also ranked (Table 2, Figure 2). These authors were 
responsible for $42.4 \%$ of all scientific publications on this subject and produced 133.24 papers on average. Three institutions, all Chinese, published more than 2,000 papers (Table 3): the Guangzhou Institute of Respiratory Health, the Lanzhou University, and the National Institutes for Food and Drug Control.

Table 2 - The 150 most-productive authors' countries publishing about Swine Flu from December 2009 to December 2010 and about COVID-19 from December 2019 to December 2020 in journals indexed in the PubMed database.

\begin{tabular}{|c|c|c|c|}
\hline \multicolumn{2}{|c|}{ Swine Flu } & \multicolumn{2}{|c|}{ COVID-19 } \\
\hline Country & Papers & Country & Papers \\
\hline China & 738 & China & 17,476 \\
\hline USA & 548 & USA & 855 \\
\hline Hong Kong & 144 & India & 367 \\
\hline Japan & 135 & Taiwan & 363 \\
\hline Singapore & 89 & Canada & 351 \\
\hline Australia & 50 & Korea & 107 \\
\hline Canada & 43 & Hong Kong & 92 \\
\hline Thailand & 41 & Italy & 90 \\
\hline France & 38 & Australia & 79 \\
\hline UK & 37 & Nepal & 74 \\
\hline Netherlands & 25 & & \\
\hline Poland & 18 & & \\
\hline India & 13 & & \\
\hline Italy & 10 & & \\
\hline Germany & 9 & & \\
\hline Vietnam & 9 & & \\
\hline Russia & 8 & & \\
\hline
\end{tabular}

Source: Research data. 


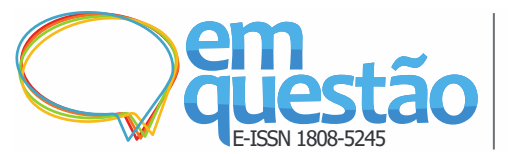

Publishing during a pandemic: comparison of scientific knowledge between COVID-19 and Swine Flu Bianca Pinto Vieira

Figure 2 - Distribution of the 150 most-productive author's institutions publishing about Swine Flu (A.) from December 2009 to December 2010 and about COVID-19 (B.) from December 2019 to December 2020 in journals indexed in the PubMed database.
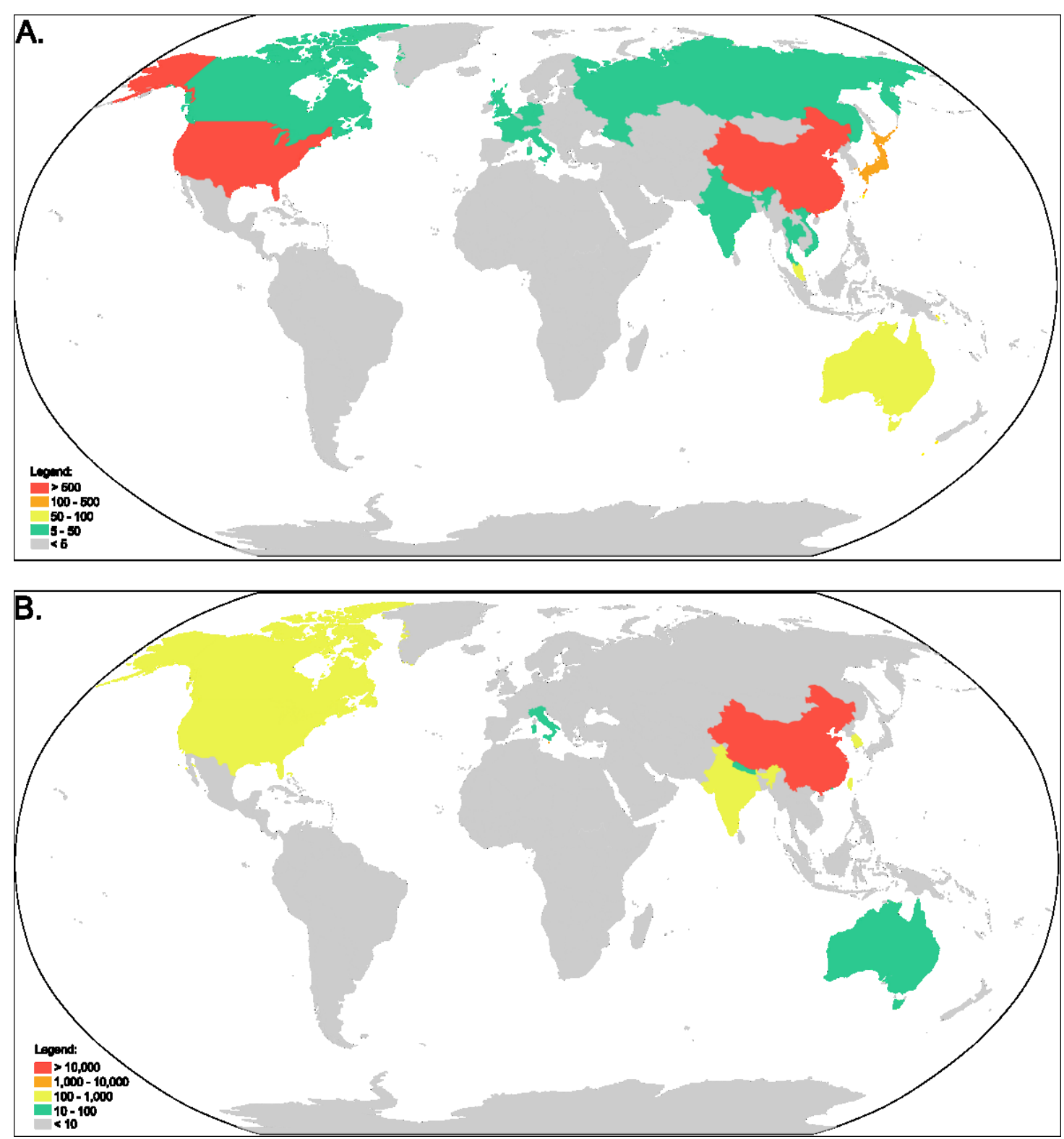

Source: Research data. 
Table 3 - The 150 most-productive authors' institutions publishing about Swine Flu from December 2009 to December 2010 and about COVID-19 from December 2019 to December 2020 in journals indexed in the PubMed database.

Swine Flu

Institution
Papers

University of Hong Kong (HK)

Harbin Medical University (CN)

Centers for Disease Control and Prevention (USA)

China Agricultural University (CN)

National Institutes of Health (USA)

Tan Tock Seng Hospital (SG)

Tsinghua University (CN)

Huazhong Agricultural University (CN)

Guangdong Academy of Agricultural Sciences $(\mathrm{CN})$

Chinese Center for Disease Control and Prevention (CN)

National Animal Disease Center (USA)

National Institutes of Health (USA)

Niigata University (JP)

Harvard Medical School (USA)

Chinese Academy of Agricultural Sciences $(\mathrm{CN})$

University of Pittsburgh (USA)

National Influenza Centre (FR)

University of Tokyo (JP)

Wuhan No. 1 Hospital (CN)

Institute of Microbiology $(\mathrm{CN})$

Wiwanitki House (TH)

Winthrop-University Hospital (USA)
144
COVID-19
Papers

National Institutes for Food and Drug Control $(\mathrm{CN})$

Guangzhou Institute of Respiratory Health $(\mathrm{CN})$

Wenzhou Medical University (CN)

Fudan University (CN)

960

Harbin Medical University (CN)

Peking Union Medical College (CN)

The Academy of Military Medical Science Institute of Microbiology and Epidemiology $(\mathrm{CN})$

Jinan University $(\mathrm{CN})$

664

Capital Medical University (CN)

Centers for Disease Control and Prevention (USA)

National Central University (TW)

Chinese Academy of Agricultural Sciences (USA)

Huoshenshan Hospital (CN)

Wuhan University (USA)

China Agricultural University (USA)

Tongji Hospital (CN)

Harvard Medical School (USA)

University of Science and Technology of China $(\mathrm{CN})$

Heidelberg University (DE) 


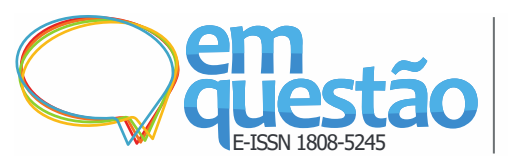

Publishing during a pandemic: comparison of scientific knowledge between COVID-19 and Swine Flu Bianca Pinto Vieira

National Institute of Public Health and Environmental Protection (NL)

Hebei North University (CN)

Wuhan University (CN)

Yamagata University (JP)

British Columbia Centre for Disease Control (USA)

Sun Yat-sen University $(\mathrm{CN})$

Prince of Wales Hospital (AU)

South China Agricultural University (USA)

University of California (USA)

McMaster University (CA)

University of Leicester (UK)

Centre for Reference and Research on Influenza (AU)

Emory University (USA)

Chinese Academy of Sciences University (CN)

Lourdes Hospital (IN)

Icahn School of Medicine at Mount Sinai (USA)

University of Virginia (USA)

Health Protection Agency Centre for Infections (UK)

Heidelberg University (DE)

Kobe City Medical Center General Hospital (JP)

Mount Sinai School of Medicine (USA)

National Institute of Animal Health (JP)

University of Kansas (USA)

University of Michigan (USA)
213

184

University of Hong Kong (HK)

National Centre for Disease Control 


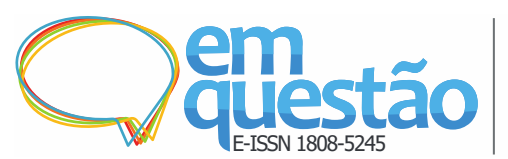

University of North Carolina (USA)

Veterinary Laboratories Agency (UK)

Chulalongkorn University (TH)

Instituto Superiore di Sanità (IT)

Lanzhou University $(\mathrm{CN})$

National Institute of Hygiene (PL)

University of Nebraska (USA)

Department of Health (AU)

Guangzhou Institute of Respiratory Health $(\mathrm{CN})$

National Centre for Veterinary Diagnostics (VN)

National University of Singapore (SG)

Robert Koch Institute (DE)

The Academy of Military Medical Science Institute of Microbiology and Epidemiology $(\mathrm{CN})$

$$
\text { Biomere (USA) }
$$

National Research Centre for Epidemiology and Microbiology (RU)

National Security Technology Department (USA)

Queen Elizabeth II Health Sciences Center (CA)

Texas Biomedical Research Institute (USA)

Université de la Méditerranée (FR)

University of Melbourne (AU)
Publishing during a pandemic: comparison of scientific knowledge between COVID-19 and Swine Flu Bianca Pinto Vieira

Source: Research data.

Papers were published in 948 journals to address the Swine Flu and in 4,234 journals to address the COVID-19. Although both pandemics are placed in the same thematic of biomedicine, the top ten journals receiving most of the publications in each subject were slightly different (Table 4). The journals PLoS 
One, Emerging Infectious Diseases (Emerg Infect Dis) and Clinical Infectious Diseases (Clin Infect Dis) stayed ahead in both lists (Table 4). While the Emerging Infectious Diseases is published by the Centers for Disease Control and Prevention (CDC) in the USA, the Clinical Infectious Diseases is published by the Oxford University Press, and PLoS One is published by the Public Library of Science in the USA.

Table 4 - List of top ten journals indexed in the PubMed database with more publications about Swine Flu from December 2009 to December 2010 and about COVID-19 from December 2019 to December 2020.

\section{Swine Flu}

COVID-19

\begin{tabular}{cccc} 
Journal & Papers & Journal & Papers \\
\hline PLoS One & 124 & J Med Virol & 637 \\
Emerg Infect Dis & 109 & Clin Infect Dis & 398 \\
J Virol & 100 & Int J Infect Dis & 389 \\
Vaccine & 96 & Int J Environ Res Public Health & 370 \\
Clin Infect Dis & 66 & Nature & 309 \\
Euro Surveill & 56 & Med Hypotheses & 307 \\
BMJ & 52 & Emerg Infect Dis & 287 \\
J Infect Dis & 44 & Sci Total Environ & 280 \\
J Clin Microbiol & 41 & PLoS One & 279 \\
N Engl J Med & 34 & J Infect & 258 \\
\hline
\end{tabular}

Source: Research data.

The papers' titles addressing the Swine Flu used mostly words such as "vaccin" and "infect" (Figure 3). The words such as "patient", "cell”, "novel", "clinic", "severe", “detect", "health" and “immun" (Figure 3) suggest publications reporting results of trials of methods to detect the disease and vaccine the population. Surprisingly, three most-used words for COVID-19 were "patient", "pandem", "infect" (Figure 4), suggesting most of the papers report clinical and descriptive results. Despite the expectations, papers on COVID-19 did not address in their top ten words terms such as "vaccin" or 
"treat" (Figure 4). However, I noticed interesting words such as "review", "care", and "impact" (Figure 4).

Figure 3 - Word cloud (A.) and frequency of words (B.) used in titles of publications indexed in the PubMed database about Swine Flu from December 2009 to December 2010.

A.

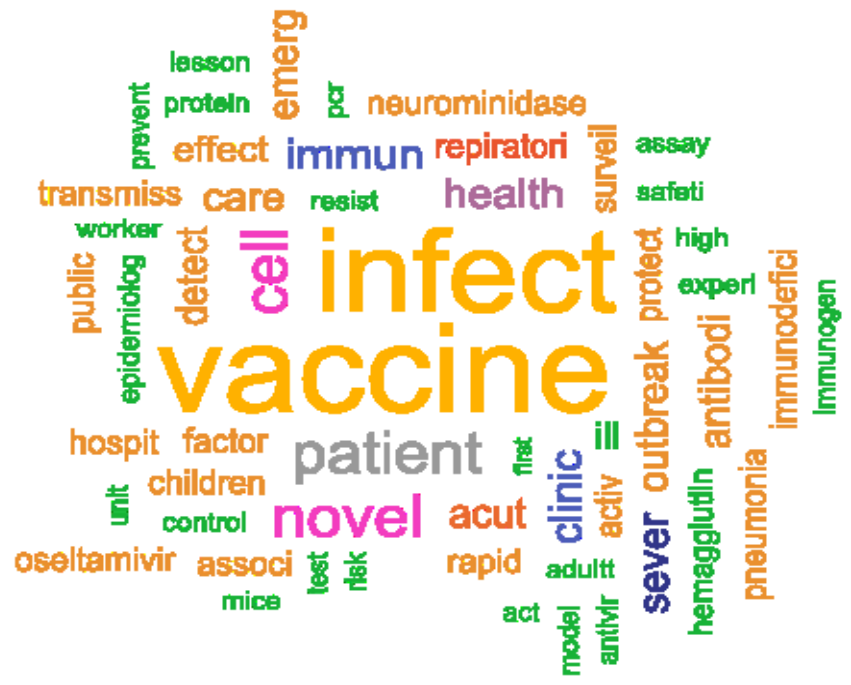

B.

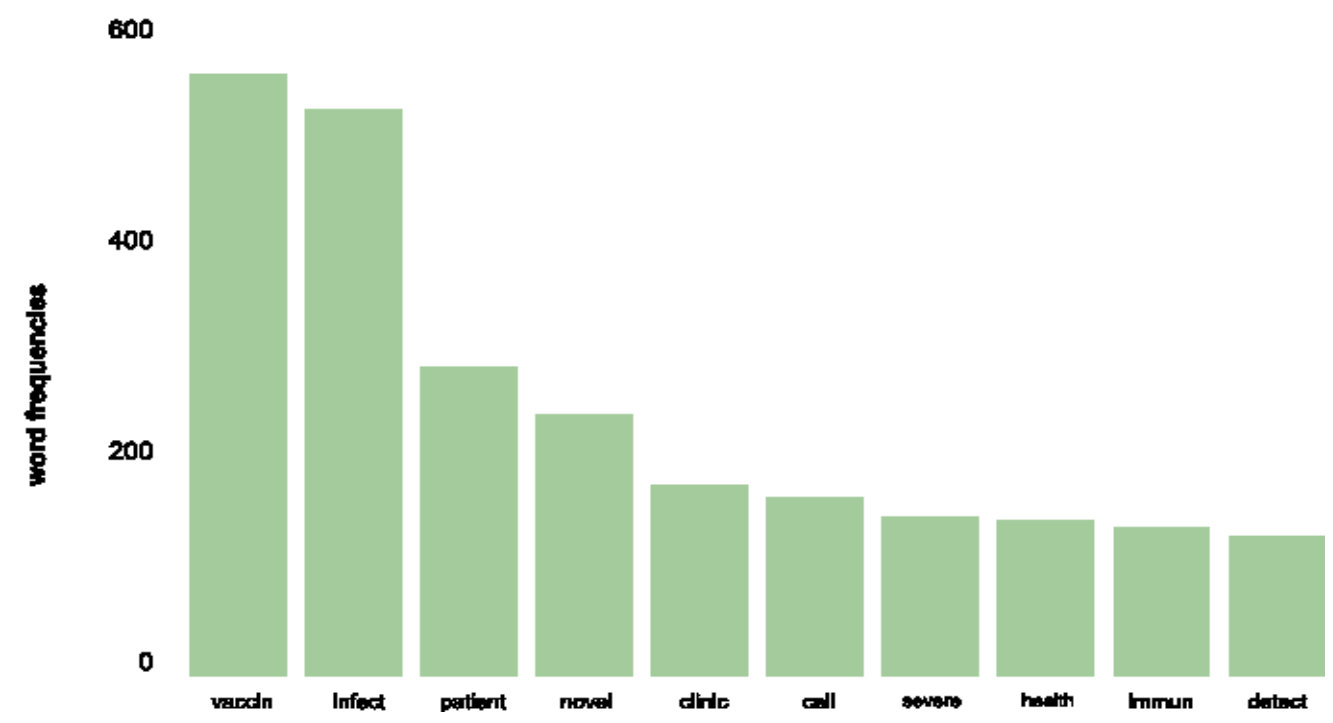

Source: Research data. 
Figure 4 - Word cloud (A.) and frequency of words (B.) used in titles of publications indexed in the PubMed database about COVID-19 from December 2019 to December 2020.

A.

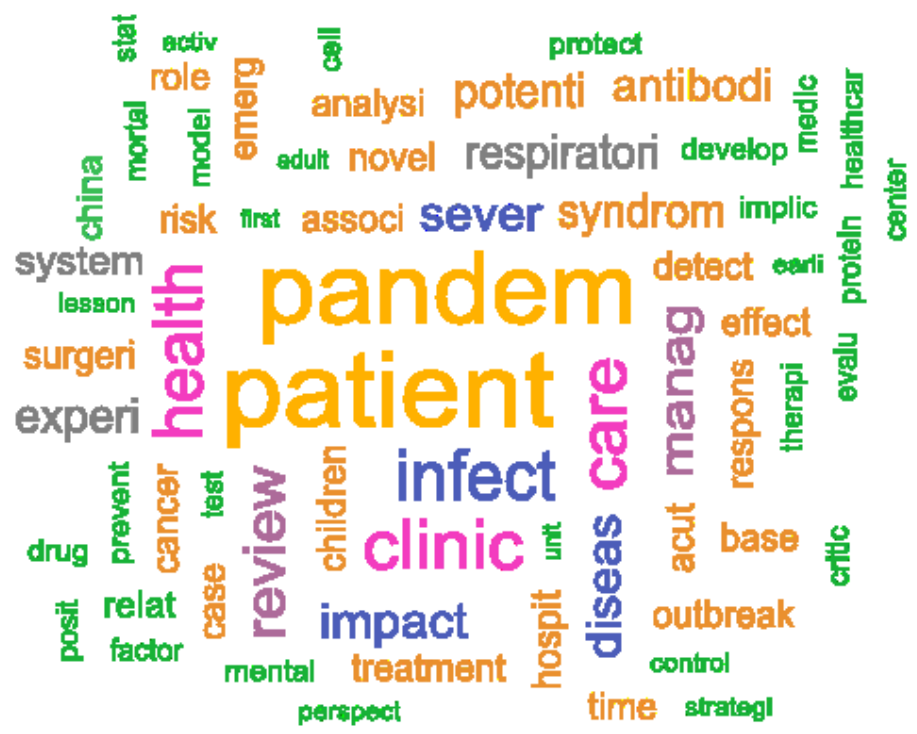

B.

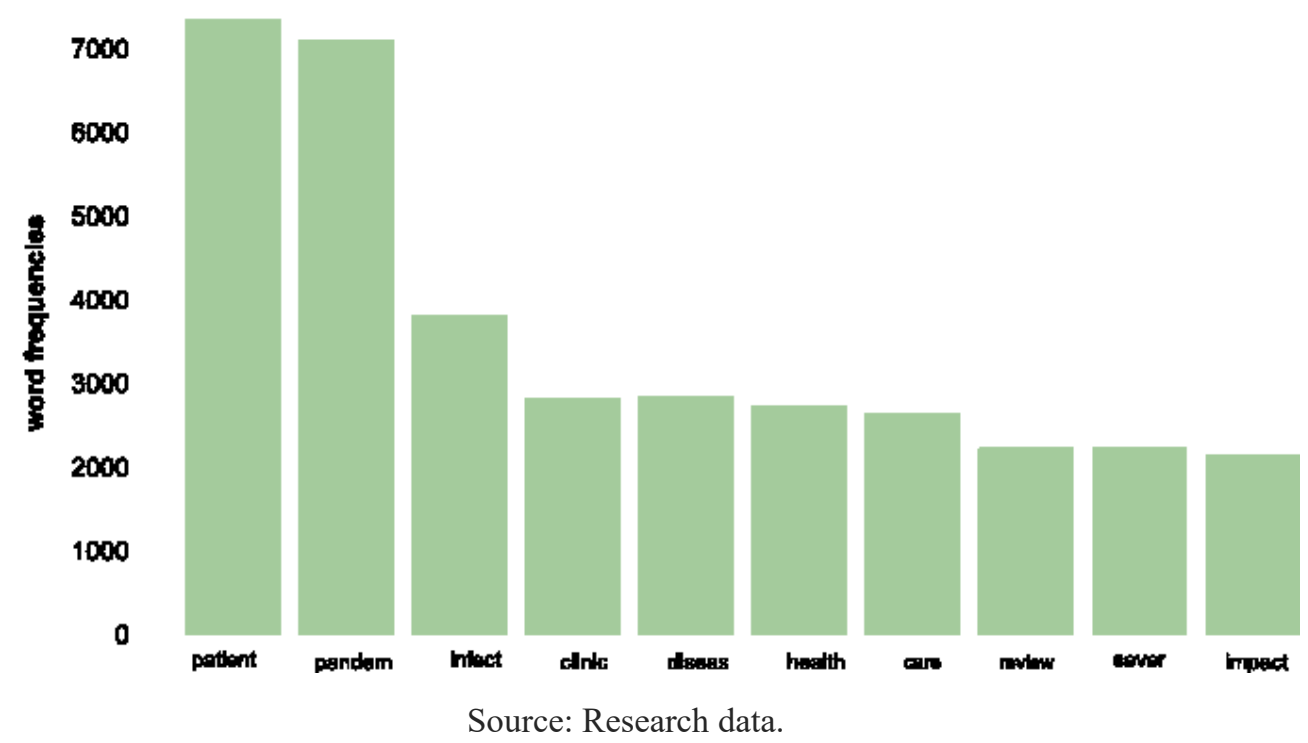

\section{Discussion}

Considering the one-year timeframe during both pandemics, I found that academic publishing on COVID-19 was 11 times higher than on Swine Flu. These results corroborate the hypothesis that speed and volume of publications about the COVID-19 would be greater than about the Swine Flu. There were significant trends on publications during the peak of each pandemic, with COVID-19 increasing over time and Swine Flu decreasing. The Swine Flu pandemic happened from January 2009 to August 2010, but its peak of 
publications considering studies from 1919 to 2020 was in January 2011 (n = 557), out of the selected timeframe. Though vaccination for COVID-19 started in December 2020, it is likely a new peak of publications on COVID-19 might occur in 2021 as the observed pattern for Swine Flu. However, I can surely state that the COVID-19 is the most-studied pandemic of history up to now.

Possibly the reason for this astonishing difference is related to each pandemic's impact in our society and to a natural increase in scientific production. The transmission and mortality rates of COVID-19 are 2.79 and 3.4\%, while Swine Flu's rates are 1.6 and $0.02 \%$ respectively (WHO, 2010b; LIU et al., 2020a; LOEFFLER-WIRTH et al., 2020). The economic impact of COVID-19 on society is estimated at US\$17 trillion in contrast to Swine Flu, which had an estimated impact of US\$360 billion (SMITH et al., 2011; MCKIBBIN; FERNANDO, 2020). Moreover, the Swine Flu was already known since its variants of H1N1 resulted in the Spanish Flu pandemic in 1919 therefore not a novelty for scientific studies. On the other hand, COVID-19 was just found in 2019 (WHO, 2020) and has been fast spreading causing a great impact in society thus any aspects about this disease worth publishing.

The increase in the number of publications about the COVID-19 was also possible because, in the last decade, the scientific community witnessed an expansion of platforms and papers available online (COSTELLO, 2009). As the world is more connected and collaborations are more easily established, I expected papers focusing on the COVID-19 would have a higher diversity of countries and institutions collaborating. However, results rejected the hypothesis and pointed out that publications on the COVID-19 were more concentrated in one country (China).

The collaboration index for papers addressing the COVID-19 was also lower than for papers addressing the Swine Flu. According to Rodrigues et al. (2020), papers are related to the scientific activity of a country and its institutions. In every country, scientific publications are fundamental in the quality evaluation of researchers and institutions (RODRIGUES et al., 2020). Number and quality of publications usually reflect the country's investments in science and innovation as well as its economic development (MAZZUCATO, 
2014). According to the World Economic Forum (2020), the three economies with greatest GDP in 2010 were USA, China, and India while in 2020 it has already changed to China, USA, and India.

As scientific production reflects quality of developed research, it is also an indicator of reference for institutions and journal's ranking. It is interesting that although most papers about the COVID-19 came from Chinese institutions, they were still mostly published in North American and European journals. Publishing in a traditional and prestigious journal is the widest accepted form of indicating research's novelty and robustness to overcome the skepticism (RODRIGUES et al., 2020). The scientific publishing cycle is highly dependent on peer-review to avoid authors risking duplicating research or using outdated and/or inappropriate methods thus compromising conclusions (RODRIGUES et al., 2020). However, it is interesting noticing many journals accepting papers about the COVID-19 had an overall policy of publishing information as fast as they could, sometimes without peer-reviewing, and releasing preprints months in advance (EISEN et al., 2020; HOBDAY et al., 2020; PALAYEW et al., 2020).

Words in titles expressed well the focus of scientific efforts during both pandemics. Despite the expectations on studies about the COVID-19 mostly focusing on treatments and vaccines considering the impacts of this disease in society, I found quite the opposite. While the Swine Flu pandemic resulted in papers addressing mostly vaccines and treatments (including the use of the medicine oseltamivir), the papers about the COVID-19 mostly focused on reviewing information, managing the effects of the disease, testing methods for its detection, and some experimentation with drugs to find treatments. From the word cloud I can conclude it is likely most researchers studying the Swine Flu followed a linear scientific process of developing and reporting treatments and vaccines from cells to mice and later clinic results during the pandemic of 20092010. The previous knowledge on the Swine Flu's effects and its impacts on society would possibly not add to that moment. However, the recently discovered COVID-19 showed a much more dispersed focus. Moreover, the papers on the COVID-19 did not seem to follow a linear process and, in less 
than a year, with no previous knowledge, papers constantly published about clinical trials, outcomes and lessons. Considering WHO (2020) reported more than 150 vaccines being developed in the whole world during 2020 to tackle the COVID-19, and great advancements within one year, it is very surprising the world "vaccin" (cited only 785 times) did not rank. This apparent nonlinear process is also ensured by the ranked term "review", demonstrating the huge scientific effort to filter and organise all the knowledge generated by the huge volume of published papers.

Publications are the most well-established way to socially control the competency standards within the scientific research (RODRIGUES et al., 2020). As knowledge evolves in the scientific community, information is released to society and decision makers (ROWLEY, 2001). It is natural that subjects addressed in popular media might not be the same trend topics in scientific research. I noticed a particular situation where the term chloroquine and its variations (cited 483 times) did not rank thus showing it was not a priority of research however it demanded time and effort from authors.

Political and economic interests have been affecting decisions in many countries concerning, for example, the use of masks, medicines, and social distancing. Biased decisions were dangerously based on in-progress or conflicting research. Absence of critical thinking on scientific papers and cognitive dissonance - which is the reluctance to admit mistakes or change minds around something that was setup (ARONSON, 1997) -, by some groups help raise misinformation. It is the case of chloroquine that came as a good option in vitro (LIU et al., 2020b) but not in wide clinical trials (FERNER; ARONSON, 2020; BOULWARE et al., 2020; MEHRA et al., 2020).

This conflict of information and need of further studies did not only occur during the COVID-19 pandemic. Public opinion and media were responsible for driving the scientific agenda also during the Swine Flu pandemic (NORGAARD; LAZARUS, 2010). This is an interesting topic to have further research considering the concern in any pandemic is that public opinion biased by information warfare ends up pressuring health management, blocking necessary measures to get done (NORGAARD; LAZARUS, 2010). These 
findings highlight how public management must consider papers' results in decisions with caution and after technical careful reviewing (NORGAARD; LAZARUS, 2010).

The scientific community keeps parsimony and there is a learning curve created by authors pointing to studies' limitations, as well as other researchers testing conclusions and bringing concerns to a wider discussion even if the process speeds up (HACKING, 1983; DANE, 1990; ROWLEY, 2001). Scientific knowledge takes at least a few months to be properly discussed and structured for wide management use (HACKING, 1983; DANE, 1990; ROWLEY, 2001). Information can be transformed into intelligence thus a fundamental asset to successful management in any situation, but the cycle of information management must be aligned with scientific knowledge. Understanding how information is built by the Academia and establishing tailoring and filtering thus is essential in a proper decision-making process (NORGAARD; LAZARUS, 2010; DUTRA; BARBOSA, 2020).

\section{Conclusion}

As the world has witnessed, a pandemic with immediate impact on human lives urges scientific methods to speed up finding solutions. These results corroborate the hypothesis that speed and volume of publications about the COVID-19 would be greater than about the Swine Flu. The number of publications about COVID-19 was 11 times higher than the number of publications about Swine Flu in a one-year timeframe. Though I expected more international collaborations and studies focusing on vaccines for COVID-19, papers were mostly concentrated in China and studying symptoms, managing the pandemic, reviewing knowledge, or establishing clinical trials. I also found papers about the Swine Flu addressed mostly vaccines and treatments (including the use of the medicine oseltamivir).

For sure, science is working faster every day for solutions in biomedical critical situations. However, the fast volume of information might blurry decisions on public health management. Future studies could focus on how the scientific process of development and reporting research changes over time and 
specially how the media (e.g., social media, news, popular discussions, and believes) could be redirecting this process. There is also opening for interesting further research on the influence of world economic, political, and cultural positioning in countries over the approach and thematic of scientific publications.

Moreover, this paper's results show it is mandatory stablishing critical thinking and waiting for the scientific community to first progress on its scientific knowledge cycle and mature discussions on the generated knowledge before using papers to justify taking action.

\section{Acknowledgements}

Thanks to PubMed ${ }^{\circledR}$ and Daniella Vieira for helping on data extraction, and to Ana Clara Cândido for helping establish and calibrate the methods, discussing results and implications, and overall reviewing.

\section{References}

AKIN, Levent; GÖZEL, Mustafa Gökhan. Understanding dynamics of pandemics. Turkish Journal of Medical Science, Istanbul, v. 50, n. SI-1, p. 515-519, 2020.

ARONSON, Elliot. Back to the future: Retrospective review of Leon Festinger's "A Theory of Cognitive Dissonance". The American Journal of Psychology, Illinois, v. 110, n. 1, p. 127-137, 1997.

BAUM, Robert; WALLY, Stefan. Strategic decision speed and firm performance. Strategic management journal, Maryland, v. 24, n. 11, p. 1107$1129,2003$.

BOULWARE, David et al. A randomized trial of hydroxychloroquine as postexposure prophylaxis for Covid-19. The New England Journal of Medicine, Massachusetts, v. 383, p. 517-525, 2020.

COSTELLO, Mark. Motivating online publication of data. BioScience, Oxford, v. 59, n. 5, p. 418-427, 2009.

DANE, Francis. Research Methods. Pacific Grove: Brooks Cole, 1990.

DI MASCIO, Daniele et al. Risk factors associated with adverse fetal outcomes in pregnancies affected by Coronavirus disease 2019 (COVID-19): A secondary 
analysis of the WAPM study on COVID-19. Journal of Perinatal Medicine, Berlin, v. 48, n. 9, p. 950-958, 2020.

DUTRA, Frederico Giffoni de Carvalho; BARBOSA, Ricardo Rodrigues. Modelos e etapas para a gestão da informação: uma revisão sistemática de literatura. Em Questão, Porto Alegre, v. 26, n. 2, p. 106-131, 2020.

EISEN, Michel et al. Peer Review: Publishing in the time of COVID-19. Elife, Cambridge, v. 9, p. e57162.

FEINERER, Ingo; HORNIK, Kurt. Text Mining Package. 2019. Available at: http://tm.r-forge.r-project.org. Access in: 10 Jan. 2021.

FELLOWS, Ian. Word Clouds. 2018. Available at:

http://blog.fellstat.com/?cat=11. Access in: 10 Jan. 2021.

FERNER, Robin; ARONSON, Jeffrey. Chloroquine and hydroxychloroquine in covid-19. BMJ, London, v. 369, p. m1432, 2020.

HACKING, Ian. Representing and Intervening. Cambridge: University Press, 1983.

WICKHAM, Hadley. httr: Tools for Working with URLs and HTTP. 2019a. Available at: https://github.com/r-lib/httr. Access in: 10 Jan. 2021.

WICKHAM, Hadley. Easily Harvest (Scrape) Web Pages. 2019b. Available at: https://github.com/tidyverse/rvest. Access in: 10 Jan. 2021.

WICKHAM, Hadley. xml2: Parse XML. 2020. Available at: https://github.com/r-lib/xml2. Access in 10 Jan. 2021.

HOBDAY, Alistair; BROWMAN, Howard; BOGRAD, Steven. Publishing and peer reviewing as indicators of the impact of COVID-19 on the productivity of the aquatic science community. ICES Journal of Marine Science, Storebø, v. 77., n. 7-8, p. 2439-2444, 2020.

L'VOV, Dmitry et al. A possible association of fatal pneumonia with mutations of pandemic influenza A/H1N1 sw1 virus in the receptor-binding site of the HA1 subunit. Voprosy virusologii, Moscow, v. 55, n. 4, p. 4-9, 2010.

LIU, Jia et al. Hydroxychloroquine, a less toxic derivative of chloroquine, is effective in inhibiting SARS-CoV-2 infection in vitro. Cell Discovery, New York, v. 6, p. 16, 2020b.

LIU, Ying et al. The reproductive number of COVID-19 is higher compared to SARS coronavirus. Journal of Travel Medicine, Oxford, v. 27, n. 2, p. taaa021, 2020a. 
LOEFFLER-WIRTH, Henry; SCHMIDT, Maria; BINDER, Hans. Covid-19 Transmission Trajectories: Monitoring the Pandemic in the Worldwide Context. Viruses, New York, v. 12, n. 7, p. 777, 2020.

MAZZUCATO, Mariana. 2014. O estado empreendedor: desmascarando o mito do setor público vs. Privado. São Paulo: Portfólio-Penguin.

MCKIBBIN, Warwick; FERNANDO, Roshen. The economic impact of COVID-19. Economics in the Time of COVID-19, Sydney, v. 45, p. 45-116, 2020.

MEHRA, Mandeep et al. Hydroxychloroquine or chloroquine with or without a macrolide for treatment of COVID-19: a multinational registry analysis. The Lancet, London, v. 396, n. 10245, p. 18-24, 2020.

NORGAARD, Ole; LAZARUS, Jeffrey. Searching PubMed during a pandemic. PloS One, Berkeley, v. 5, n. 4, p. e10039, 2010.

PALAYEW, Adam et al. Pandemic publishing poses a new COVID-19 challenge. Nature Human Behaviour, New York, v. 4, n. 7, p. 666-669, 2020.

PUBMED. PubMed Overview. 2020. Available at:

https://pubmed.ncbi.nlm.nih.gov/about. Access in: 5 Jan. 2021.

R CORE DEVELOPMENT TEAM. R: A Language and Environment for Statistical Computing 4.0.2. Vienna: R Foundation for Statistical Computing, 2020.

RODRIGUES, Rosangela Schwarz; NEUBERT, Patricia da Silva; DE ARAÚJO, Breno Kricheldorf Hermes. The publications of Brazilian authors: access, distribution and publishers. Em Questão, Porto Alegre, v. 26, n. 2, p. 13-31, 2020.

ROWLEY, Jennifer. Knowledge management in pursuit of learning: the learning with knowledge cycle. Journal of Information Science, London, v. 27, n. 4, p. 227-237, 2001.

SAUNDERS-HASTINGS, Patrick; KREWSKI, Daniel. Reviewing the history of pandemic influenza: understanding patterns of emergence and transmission. Pathogens, Warwick, v. 5, n. 4, p. 66, 2016.

SINGH, Akriti et al. COVID-19: From bench to bed side. Diabetes \& Metabolic Syndrome: Clinical Research \& Reviews, Delhi, v. 14, p. 277-81, 2020.

SMITH, C. A. P.; HAYNE, Stephen C. Decision making under time pressure: an investigation of decision speed and decision quality of computer-supported 
groups. Management Communication Quarterly, Thousand Oaks, v. 11, n. 1, p. 97-126, 1997.

SMITH, Richard; KEOGH-BROWN, Marcus; BARNETT, Tony. Estimating the economic impact of pandemic influenza: an application of the computable general equilibrium model to the UK. Social science \& medicine, Boston, v. 73, n. 2, p. 235-244, 2011.

TRIFONOV, Vladimir; KHIABANIAN, Hossein; RABADAN, Raul. Geographic dependence, surveillance, and origins of the 2009 influenza A (H1N1) virus. The New England Journal of Medicine, Massachusetts, v. 361, n. 2, p. 115-119, 2009.

WHO, World Health Organization. Procedure for assessing the acceptability, in principle, of vaccines for purchase by United Nations agencies. Geneva: WHO Technical Report Series. 2010a

WHO, World Health Organization. Pandemic (H1N1) 2009. 2010b. Available at: https://apps.who.int/iris/handle/10665/205605. Access in: 24 June. 2021.

WHO, World Health Organization. Naming the coronavirus disease (COVID19) and the virus that causes it. 2020. Available at:

https:/www.who.int/emergencies/diseases/novel-coronavirus-2019/technicalguidance/naming-the-coronavirus-disease-(covid-2019)-and-the-virus-thatcauses-it. Access in: 15 Jan. 2021.

WORLD ECONOMIC FORUM. Largest global economies. 2020. Available at: https://www.weforum.org/agenda/2020/07/largest-global-economies-19922008-2024. Access in: 15 Jan. 2021.

\section{Publicando durante uma pandemia: comparação do conhecimento científico durante as crises causadas pela COVID- 19 e pela Gripe Suína}

Resumo: O conhecimento científico tem um ciclo bem estabelecido de criação de hipóteses, testando-as em experimentos e submetendo-as à análise da comunidade científica por meio de publicações. Leva-se tempo para atingir suficiência amostral em estudos biomédicos, especialmente sobre o efeito de medicamentos e vacinas. O protocolo da Organização Mundial da Saúde estima que sejam necessários mais de 19 meses de experimentos para aprovar uma vacina, por exemplo. Uma pandemia com impacto imediato em vidas humanas exige que estudos científicos acelerem a busca de soluções. No presente trabalho, avaliamos a velocidade e o volume de informações geradas pela 
Academia para enfrentar a COVID-19 em comparação com a Gripe Suína. Foram considerados artigos de periódicos indexados na plataforma PubMed. O número de publicações sobre a COVID-19 foi 11 vezes maior que o número de publicações sobre a Gripe Suína no período de um ano. Embora esperássemos mais colaborações e estudos internacionais com foco em vacinas para a COVID19, os artigos se concentraram na China e no estudo de sintomas, gerenciamento da pandemia, revisões do conhecimento ou em ensaios clínicos. Com certeza, a Ciência está trabalhando mais rápido para soluções em situações biomédicas críticas. No entanto, o grande volume de informações gerado em pouco tempo pode dificultar a tomada de decisões em diversas áreas, incluindo na gestão da saúde. Os resultados deste artigo mostram que antes de usar artigos para realizar ações, os tomadores de decisão devem filtrar as informações recebidas e aguardar que a comunidade científica amadureça as discussões sobre o conhecimento gerado.

Palavras-chave: Coronavírus; Doença viral; Banco de dados Pubmed; Informação de valor; Ciclo do conhecimento científico

Recebido: $16 / 02 / 2021$

Aceito: 02/06/2021

\section{Declaração de autoria}

Concepção e elaboração do estudo: Bianca Vieira.

Coleta de dados: Bianca Vieira.

Análise e interpretação de dados: Bianca Vieira.

Redação: Bianca Vieira.

Revisão crítica do manuscrito: Bianca Vieira.

\section{Como citar:}

VIEIRA, Bianca Pinto. Publishing during a pandemic: comparison of scientific knowledge between COVID-19 and Swine Flu. Em Questão, Porto Alegre, v. 28, n. 2, e-111566, abr./jun. 2022. https://doi.org/10.19132/18085245282.111566

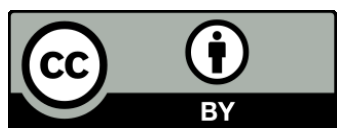

